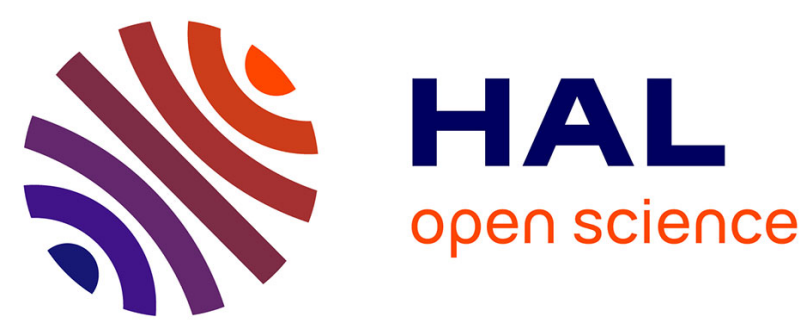

\title{
Augmentation of protein synthesis and degradation by poor dietary amino acid balance in european sea bass (Dicentrarchus labrax)
}

\author{
Habib Langar, Jean Guillaume, Robert Metailler, Benoit Fauconneau
}

\section{- To cite this version:}

Habib Langar, Jean Guillaume, Robert Metailler, Benoit Fauconneau. Augmentation of protein synthesis and degradation by poor dietary amino acid balance in european sea bass (Dicentrarchus labrax). Journal of Nutrition, 1993, 123, pp.1754-1761. hal-02702418

\section{HAL Id: hal-02702418 \\ https://hal.inrae.fr/hal-02702418}

Submitted on 1 Jun 2020

HAL is a multi-disciplinary open access archive for the deposit and dissemination of scientific research documents, whether they are published or not. The documents may come from teaching and research institutions in France or abroad, or from public or private research centers.
L'archive ouverte pluridisciplinaire HAL, est destinée au dépôt et à la diffusion de documents scientifiques de niveau recherche, publiés ou non, émanant des établissements d'enseignement et de recherche français ou étrangers, des laboratoires publics ou privés. 


\title{
Nutrient Requirements and Interactions
}

\section{Augmentation of Protein Synthesis and Degradation by Poor Dietary Amino Acid Balance in European Sea Bass (Dicentrarchus labrax) ${ }^{1}$}

\author{
HABIB LANGAR, JEAN GUILLAUME, *² ROBERT METAILLER \\ AND BENOÎT FAUICONNEAU ${ }^{\dagger}$
}

\author{
IFREMER Brest, Laboratoire de Nutrition, B.P 70, 29280 Plouzane, France; *INRA/IFREMER \\ Brest, Laboratoire de Nutrition, B.P 70, 29280 Plouzane, France; and TINRA Rennes, \\ Laboratoire de Physiologie des Poissons, Campus de Beaulieu, 35042 Rennes, France
}

\begin{abstract}
Sea bass fry were fed a fixed ration of one of six isonitrogenous diets differing in essential amino acid balance or physical and chemical state of the protein source (Hydrolysate vs. intact protein) to induce different growth rates. The reference diet was based on fish meal, whereas the other diets contained fish protein hydrolysate, greaves meal (i.e., defatted collagen meal) or hydrolyzed feather meal added at 30 or $50 \%$ of crude protein at the expense of fish meal protein. Digestibility as well as fractional rate of whole-body protein synthesis was assessed. Whole-body protein synthesis was determined for each group of fish using a single injection of flooding dose of tritiated phenylalanine. Protein digestibility of the diets varied only by $5.5 \%$. Specific growth rate and fractional protein specific growth rate, i.e., fractional protein accretion, were higher in fish fed the reference diet than in those fed the diets in which $50 \%$ of fish meal protein had been replaced by greaves or hydrolyzed feather meal protein. Compared with the reference group, whole-body protein synthesis was higher in fish fed these latter diets as well as in those fed the diet containing $30 \%$ greaves meal protein. The fractional protein accretion to fractional protein synthesis ratio, i.e., the efficiency of protein deposition, was lower in fish fed poorer dietary amino acid balance than in the reference group. The substitution of fish protein hydrolysate for intact fish protein led to a similar, though less pronounced phenomenon: nonsignificant increase in protein synthesis accompanied by significant increase in protein degradation. The increase in whole-body protein synthesis rate was linked to an increase in the amount of whole-body RNA, but the efficiency of ribosomal activity was not significantly different. Thus, decreased growth rate seemed to be a result of an increase in protein degradation. J. Nutr. 123: 1754-1761, 1993.
\end{abstract}

INDEXING KEY WORDS:

- fish - protein - amino acids

- turnover - growth
The improvement of dietary amino acid balance to induce faster growth does not always lead to a greater rate of protein synthesis. Both in pigs (Fuller et al. 1987) and in chickens (Tesseraud et al. 1992), supplementation of deficient diets with lysine reduced protein degradation without a clear effect on protein synthesis. The aim of the present work was to study the relationship between amino acid balance and protein synthesis or degradation in fry of a marine fish, the sea bass Dicentrarchus labrax. Amino acid balance was modified by partial substitution of poor protein sources (greaves meal and feather meal) for the protein source commonly used in fish nutrition (i.e., fish meal); fish protein hydrolysate was also used to impair protein efficiency without disturbing amino acid balance. Previous unpublished work in our laboratory has shown that the nitrogen digestibility of these ingredients, including fish meal, was very similar.

Among the methods proposed to evaluate protein synthesis and degradation in fish, the flooding dose method (Garlick et al. 1980) seems to be the most appropriate. However, to our knowledge, it had never been used in 1- to 5-g fingerlings.

Two experiments were conducted: Experiment 1 was mainly a methodological trial to verify the validity of the method of Garlick et al. (1980) in very young sea bass; Experiment 2 was conducted to evaluate the effects of dietary amino acid balance on growth, protein synthesis and degradation. Both experiments were performed on fish of the same origin and reared during the same period.

\footnotetext{
${ }^{1}$ The costs of publication of this article were defrayed in part by the payment of page charges. This article must therefore be hereby marked "advertisement" in accordance with 18 USC section 1734 solely to indicate this fact.

${ }^{2}$ To whom correspondence should be addressed.
} 

TABLE 1

Composition of the experimental diets

\begin{tabular}{|c|c|c|c|c|c|c|}
\hline & \multicolumn{6}{|c|}{ Diet } \\
\hline & REF & $\mathrm{H} 30$ & $\mathrm{H} 50$ & G30 & G50 & F50 \\
\hline \multicolumn{7}{|l|}{ Ingredient, $g / \mathrm{kg}$} \\
\hline Norway fish meal $70^{1}$ & 710.4 & 497.3 & 355.2 & 497.3 & 355.2 & 355.2 \\
\hline Fish protein concentrate $83^{2}$ & - & 180.5 & 300.8 & - & - & - \\
\hline Greaves meal $67^{3}$ & - & - & - & 223.5 & 372.5 & - \\
\hline Hydrolyzed feather meal $80^{3}$ & - & - & - & - & - & 312.7 \\
\hline Cooked cornstarch & 150.0 & 150.0 & 150.0 & 150.0 & 150.0 & 150.0 \\
\hline Sodium alginate & 40.0 & 40.0 & 40.0 & 40.0 & 40.0 & 40.0 \\
\hline Vitamin mixture 4 & 10.0 & 10.0 & 10.0 & 10.0 & 10.0 & 10.0 \\
\hline Coated ascorbic acid & 1.5 & 1.5 & 1.5 & 1.5 & 1.5 & 1.5 \\
\hline Choline chloride $(50 \%)$ & 6.0 & 6.0 & 6.0 & 6.0 & 6.0 & 6.0 \\
\hline Soybean lecithin & 10.0 & 10.0 & 10.0 & 10.0 & 10.0 & 10.0 \\
\hline Cod liver oil & 34.3 & 36.5 & 38.0 & 53.0 & 54.3 & 36.6 \\
\hline Cellulose powder & 37.8 & 68.2 & 88.5 & 8.7 & 0.5 & 78.0 \\
\hline \multicolumn{7}{|l|}{ Analysis } \\
\hline Crude protein $(\mathrm{N} \times 6.25)$, \% & 49.5 & 49.9 & 50.1 & 49.8 & 50.5 & 51.0 \\
\hline Gross energy, $M / / \mathrm{kg}$ & 19.9 & 19.0 & 19.2 & 19.1 & 18.7 & 19.7 \\
\hline \multicolumn{7}{|c|}{$\begin{array}{l}{ }^{1} \text { Norseamink }{ }^{\circledR} \text {; Norsildmel, Minde, Norway. } \\
{ }^{2} \text { CPSP }^{\circledR} \text {; CTPP, Boulogne sur mer, France. }\end{array}$} \\
\hline
\end{tabular}

\section{MATERIALS AND METHODS}

Experimental facilities. Experiments were conducted in $0.50 \times 0.50 \times 0.25 \mathrm{~m}$ tanks supplied with sand-filtered running sea water (salinity $=34 \mathrm{~g} / \mathrm{L}$ ) maintained at $18 \pm 1^{\circ} \mathrm{C}$. Flow rate was $\sim 3 \mathrm{~L} / \mathrm{min}$ and $\mathrm{pH}$ remained close to 8 .

Growth and feeding. Sea bass fingerlings, hatched and raised in our laboratory and weighing $1.07 \mathrm{~g}$ on average, were fed for $50 \mathrm{~d}$ a nonpurified diet (Frippak Sevbar ${ }^{\circledR}$-Sanofi-Aquaculture, Paris, France, containing $50 \%$ crude protein and $8 \%$ lipids) in Experiment 1 and six experimental diets (Table 1) in Experiment 2. The ration size was $3.5 \mathrm{~g} / 100 \mathrm{~g}$ body wt per day. The daily meal was continuously distributed over $8 \mathrm{~h}$ per day using an automatic belt feeder. The ration was adjusted every $10 \mathrm{~d}$ after weighing. Three replicates of 50 fish were used for each diet. All experimental diets (Table 1) contained $50 \%$ crude protein, 12\% lipids and $15 \%$ carbohydrates. Theoretically the protein source was the only difference between the diets, which were formulated to be isoenergetic. The reference diet (Diet REF) contained Norwegian fish meal (70\% crude protein) and was used as a control. In the other diets, fish meal was partly replaced by fish protein hydrolysate ( $83 \%$ crude protein), greaves meal, i.e., a defatted collagen meal (a by-product of the tallow and lard industry, $67 \%$ crude protein) and hydrolyzed feather meal (80\% crude protein). Fish protein hydrolysate and greaves meal were incorporated in the diet at 30 and $50 \%$ of crude protein (Diets $\mathrm{H} 30$ and $\mathrm{H} 50$ for fish protein hydrolysate and Diets G30 and G50 for greaves meal, respectively). Hydrolyzed feather meal was incorporated at the single protein level of $50 \%$ (Diet F50).

Body weights were measured at the end of the experiment after 1-d starvation, and the specific growth rate (fractional growth rate) was determined as the percentage of increase per day according to the following formula deduced from the exponential growth model (Ricker 1979):

$$
\text { Specific growth rate }=\frac{\ln \mathrm{Wf}-\ln \mathrm{Wi}}{50} \times 100(\% / \mathrm{d})
$$

where Wi and Wf are the initial and the final body weights $(\mathrm{g})$, respectively, and 50 is the number of days of the experiment.

Body composition and protein accretion. Fifteen fish were sampled in each tank, pooled, freeze-dried and used for carcass protein analyses to determine the fractional protein specific growth rate $(\mathrm{Kg}$, fractional protein accretion) according to the following formula:

$\mathrm{Kg}=$ Fractional protein specific growth rate $=$

$$
\frac{\ln \mathrm{Pf}-\ln \mathrm{Pi}}{50} \times 100(\% / \mathrm{d})
$$


where Pi and Pf are the mean protein weights (in grams) at the beginning and at the end of experiment, respectively. Carcass protein content $(\mathrm{N} \times 6.25)$ was determined by the micro-Kjeldahl technique.

This later formula was derived from Equation (1), assuming that protein growth was similar to biomass growth. In other words, body protein content being constant, protein growth or accretion was supposed to be exponential. According to this hypothesis, the protein specific growth rate is independent of time.

Amino acid analysis. Amino acids were analyzed by ion exchange chromatography. Samples were hydrolyzed in $6 \mathrm{~mol} / \mathrm{L} \mathrm{HCl}$, and amino acids were separated after ninhydrin coloration using a Beckman System 6300 analyzer (Beckman Instruments, San Ramon, CA). For sulfur amino acids, samples were submitted to performic oxidation before analysis. Norleucine was used as hydrolysis internal standard. Tryptophan was assayed, after $6 \mathrm{~mol} / \mathrm{L} \quad \mathrm{BaOH}$ hydrolysis, using a Spectra Physics HPLC apparatus (Spectra Physics, San Jose, CA) equipped with nucleosil C18 column. Absorbance was measured directly at $280 \mathrm{~nm}$.

Digestibility. Digestibility of crude protein and energy was measured using the chromic oxide indicator method, on three replicates of 150 similar fish (Spyridakis et al. 1988). The feces were collected with conical decantation tanks during a 1-wk period after $10 \mathrm{~d}$ of adaptation to the diets. Samples of feces were freeze-dried until further analysis. Protein was determined using the Kjeldahl method and gross energy with a Parr adiabatic bomb calorimeter (Parr, Moline, IL). Chromic oxide was assayed by a spectrophotometric method (Bolin et al. 1952). Digestibility of Diet F50 was determined separately because of the limited number of tanks available for fecal collection.

Trial 1: Time course of incorporation of ${ }^{3}$ H]phenylalanine. Fish were starved for $3 \mathrm{~d}$ and then injected intraperitoneally with a $7 \mathrm{~g} / \mathrm{L}$ saline solution containing $150 \mathrm{mmol}$ L-phenylalanine and L-[2,6${ }^{3} \mathrm{H}$ ]phenylalanine (Amersham International, Buckinghamshire, U.K.) at $3.7 \mathrm{GBq} / \mathrm{L}$. The dose was $1 \mathrm{~mL} /$ $100 \mathrm{~g}$ body wt, similar to that used in rats (Garlick et al. 1980). This dose represents 8 to $16 \%$ of the blood volume (Jones and Randall 1978) and was considered highly efficient for maximal flooding of the free amino acid pool in fish (Pocrnijc et al. 1983). After the injection, fish were returned to aerated water. At 2, 5, $10,20,40$ and $60 \mathrm{~min}$ after injection, fish (five per group) were killed by a transsection of the spinal cord. For each fish sampled, the intraperitoneal cavity was opened and rinsed with $7 \mathrm{~g} / \mathrm{L} \mathrm{NaCl}$; the stomach was also opened and rinsed. Whole carcasses were ground with a homogenizer in a beaker cooled with ice, and triplicate $100-\mathrm{mg}$ samples were frozen at $-70^{\circ} \mathrm{C}$ until further analysis.

Samples were treated as described by Garlick et al. (1980) and Houlihan et al. (1986 and 1988b) to de- termine the specific radioactivity of free and proteinbound phenylalanine. The time course of saturation of the free amino acid pool and of incorporation into proteins was determined.

Trial 2: Fractional rate of protein synthesis and degradation. Whole-body protein synthesis was determined for fish in each treatment group at the end of the growth experiment. On the day of injection, feeding was stopped $2 \mathrm{~h}$ after the beginning of the distribution of the daily ration. Three hours later, fish (15 per diet) were injected as described above, and killed $40 \mathrm{~min}$ after the injection. After determination of the specific radioactivities of free and proteinbound phenylalanine in the carcass ( $\mathrm{Sa}$ and $\mathrm{Sb}$, respectively), whole-body protein synthesis (Ks, expressed as grams of protein synthesized per $100 \mathrm{~g}$ of whole body weight and per dayl was calculated using the following formula (Houlihan et al. 1988a):

$$
\mathrm{Ks}=\frac{\mathrm{Sb}}{\mathrm{Sa}} \times \frac{1440}{40} \times 100(\text { in } \% / \mathrm{d})
$$

where 1440 is the number of minutes per day and 40 is the duration (in minutes) of the labeling period.

On the same samples, RNA concentration was measured after alkaline hydrolysis (Mejbaum 1939, Munro and Fleck 1969), and the protein content was measured by Lowry's method (Lowry et al. 1951).

The amount of protein being synthesized per RNA unit and per day ( $\left.\mathrm{K}_{\mathrm{RNA}}\right)$ was obtained by dividing Ks by the RNA/protein ratio [/mg protein synthesized// $\mu \mathrm{g}$ RNA.d)] (McMillan and Houlihan 1988). This can be used as an indicator of ribosomal activity (Hirsh 1967, Millward et al. 1973, Young 1970) because $~ 85 \%$ of tissue RNA is ribosomal (Pain and Clemens 1980).

Protein degradation ( $\mathrm{Kd}$ in $\% / \mathrm{d}$ ) was estimated from the difference between protein synthesis and protein accretion (Millward et al. 1975).

Statistical analysis. Treatments were compared by one-way ANOVA, and means were ranked with the Newman-Keuls multiple range test (Sokal and Rohlf 1981) at the 0.05 threshold. Time course of incorporation of labeled phenylalanine over the duration of the experiment was analyzed using linear regression.

\section{RESULTS}

Composition of diets. The amino acid compositions of Diets REF, H50, G50 and F50 are given in Table 2. The compositions of Diets H30 and G30 were deduced from the former data.

The substitution of fish protein hydrolysate for fish protein did not induce any marked change in the essential amino acid contents in comparison to Diet REF. The substitution of greaves meal for fish meal led to a clear reduction of the level of four essential amino acids: isoleucine and lysine (about $-10 \%$ ), 
TABLE 2

Essential and semi-essential amino acid composition of the diets ${ }^{1}$

\begin{tabular}{lrrrr}
\hline \multirow{4}{*}{$\begin{array}{l}\text { Amino } \\
\text { acid }\end{array}$} & REF & H50 & G50 & F50 \\
\cline { 2 - 5 } & & & $g / k g$ \\
Thr & 21.1 & 22.9 & 20.1 & 22.9 \\
Val & 27.1 & 27.3 & 27.4 & 33.6 \\
Met & 13.9 & 14.1 & 11.6 & 8.6 \\
Ile & 23.0 & 24.7 & 21.1 & 24.0 \\
Leu & 39.2 & 38.5 & 37.4 & 39.9 \\
Phe & 20.8 & 20.6 & 19.6 & 24.1 \\
Lys & 40.5 & 39.5 & 35.9 & 28.1 \\
His & 10.5 & 10.3 & 10.8 & 8.7 \\
Arg & 30.6 & 32.4 & 33.3 & 32.2 \\
Trp & 4.9 & 4.8 & 4.3 & 4.0 \\
Cys & 5.0 & 6.2 & 5.0 & 12.3 \\
Tyr & 16.4 & 17.0 & 13.5 & 15.8 \\
\hline
\end{tabular}

${ }^{1}$ Semi-essential amino acids are those that can be synthesized from essential amino acids (i.e., Cys and Tyr).

tryptophan $(-12 \%)$ and methionine $(-17 \%)$. The substitution of hydrolyzed feather meal for fish meal led to more pronounced changes in the profile of amino acids; it affected lysine $(-30 \%)$, methionine $(-38 \%)$, tryptophan $(-18 \%)$ and even histidine $(-17 \%)$.

Digestibility. Protein digestibility of Diets H30, H50 and G30 did not significantly differ from each other (Table 3); Diet REF had a slightly higher digestibility than Diets G30 and G50, and Diet G50 had a lower one than Diet H30 as well $(P<0.05)$. Although significant, these differences were very slight: $5.5 \%$ between extreme values. For energy digestibility, only Diet H30 showed a lower value than Diet REF $(P<$ 0.05 ), but the energy digestibility between all diets did not differ by more than $3 \%$.

Growth and protein concentration. Results concerning body weight change and body composition are shown on Table 4. The assumption that protein growth was exponential seems to be quite correct, because weight growth strictly followed an exponential model $(P<0.00001)$, whereas body protein concentration displayed very limited changes over the experimental period (Table 4). When compared with Diet REF, neither a $30 \%$ substitution of fish protein hydrolysate or greaves meal nor a $50 \%$ substitution of fish protein hydrolysate induced any significant change in specific growth rate. Greaves meal incorporated at the level of $50 \%$ of crude protein and hydrolyzed feather meal significantly reduced growth rate $(P<0.05)$.

Time course of incorporation of $\left[{ }^{3} \mathrm{H}\right]$ phenylalanine. Specific radioactivity of the pool of free phenylalanine in starved fish showed a rapid increase from 0 to $10 \mathrm{~min}$ after injection, followed by a plateau. No reduction of specific radioactivity between 10 and $60 \mathrm{~min}$ was observed (Fig. 1). The specific radioactivity of the protein-bound phenylalanine $(y$, in $\mathrm{mBq} / \mathrm{nmol})$ increased linearly with time $(t$, in $\mathrm{min})$ during this same period $(y=$ $-1.345 \times 10^{-4}+1.859 \times 10^{-4} t ; r=0.98$ ) (Fig. 2) (at 2 and 5 min after the injection, only traces of radioactivity were found in proteins; these values were not taken into account for the calculation of $r$ ). In accord with these results, the interval of $40 \mathrm{~min}$ after injection was chosen for the measurement of protein synthesis in Experiment 2.

Synthesis and degradation of protein. Fractional whole-body protein synthesis rate (Table 5) was significantly lower in fish fed Diet REF than in those fed Diets G30, G50 and F50. No significant difference was observed among groups fed Diets REF, H30 and H50 or among those fed Diets H30, H50, G30, G50 and F50, in spite of differences observed in specific growth rates and fractional protein growth rates.

The RNA to protein ratio (Table 5) was significantly different among groups $(P<0.05)$, being higher in the group fed Diet F50 than in those fed Diet REF, $\mathrm{H} 30$ or H50. Fractional protein degradation rate (Kd) was significantly higher in groups fed Diets G50 and F50 than in the other groups. The group fed Diet G30

TABLE 3

Protein and energy apparent digestibility coefficients of the experimental diets ${ }^{1}$

\begin{tabular}{|c|c|c|c|c|c|c|c|}
\hline & \multicolumn{5}{|c|}{ Diet } & $\mathrm{SEM}^{2}$ & $\begin{array}{l}\text { Diet } \\
\text { F50 }\end{array}$ \\
\hline Apparent protein digestibility, \% & $90.9^{\mathrm{a}}$ & $89.5^{\mathrm{ab}}$ & $87.9^{\mathrm{abc}}$ & $87.3^{\mathrm{bc}}$ & $85.9^{\mathrm{c}}$ & 0.8 & $88.3 \pm 0.9$ \\
\hline
\end{tabular}

\footnotetext{
${ }^{1}$ Values are means of three replicates. Values in a row not sharing a common superscript letter are significantly different $(P<0.05)$.

${ }^{2}$ Pooled SEM from one-way ANOVA.

${ }^{3}$ Not included in the statistical analysis because the digestibility determination was performed separately; values are means \pm SEM for three replicates.
} 
TABLE 4

Initial and final weight and whole-body protein concentration, specific growth rate and food intake of fish fed the experimental diets for $50 \mathrm{~d}^{1}$

\begin{tabular}{|c|c|c|c|c|c|c|c|}
\hline & \multicolumn{6}{|c|}{ Dietary group } & \multirow[b]{2}{*}{$\mathrm{SEM}^{2}$} \\
\hline & REF & $\mathrm{H} 30$ & $\mathrm{H} 50$ & G30 & G50 & F50 & \\
\hline Initial weight, $g$ & 1.03 & 1.02 & 1.04 & 1.06 & 1.13 & 1.12 & 0.03 \\
\hline Final weight, $g$ & $3.52^{\mathrm{a}}$ & $3.59^{\mathrm{a}}$ & $3.53^{\mathrm{a}}$ & $3.54^{\mathrm{a}}$ & $3.43^{\mathrm{a}}$ & $3.21^{\mathrm{b}}$ & 0.04 \\
\hline Specific growth rate, $\% / d$ & $2.45^{\mathrm{a}}$ & $2.52^{\mathrm{a}}$ & $2.44^{\mathrm{a}}$ & $2.41^{\mathrm{ab}}$ & $2.21^{\mathrm{bc}}$ & $2.11^{\mathrm{c}}$ & 0.05 \\
\hline $\begin{array}{l}\text { Initial whole body protein, } \\
\text { mg/g wet matter }\end{array}$ & 153.3 & 153.3 & 153.3 & 153.3 & 153.3 & 153.3 & 1.6 \\
\hline $\begin{array}{l}\text { Final whole body protein, } \\
\mathrm{mg} / \mathrm{g} \text { wet matter }\end{array}$ & 145.6 & 137.0 & 141.1 & 143.4 & 141.5 & 145.7 & 2.0 \\
\hline Food intake, ${ }^{4} \mathrm{~g}$ & 2.84 & 2.88 & 2.87 & 2.88 & 2.86 & 2.70 & 0.09 \\
\hline
\end{tabular}

${ }^{1}$ Values are means \pm SEM for three replicates of 50 fish per group, except for the final whole-body protein concentration, where values are means \pm SEM for three replicates of 15 pooled fish per group. Values in a row not sharing a common superscript letter are significantly different $(P<0.05)$.

${ }^{2}$ Pooled SEM from one-way ANOVA.

${ }^{3}$ Estimated by analysis of an initial pool; $n=3$ replicates of 15 fish.

${ }^{4}$ Over the $50 \mathrm{~d}$ of the experiment.

had a greater Kd than groups fed Diets REF, H30 and H50. When fish protein hydrolysate was incorporated into the diet, fish fed the diet containing the higher level of incorporation had a greater $\mathrm{Kd}(P<0.05)$.

Protein deposition and ribosomal activity. Expressed as a percentage of the daily rate of protein synthesis ( $\mathrm{Kg}$ divided by $\mathrm{Ks}$ as a percentage), the efficiency of protein deposition tended to be lower in groups having the lower specific growth rate (Table 6). The efficiency of ribosomal activity ( $\mathrm{K}_{\mathrm{RNA}}$ ) [expressed as (mg synthesized protein)/( $\mu$ g RNA.d)] did not significantly differ among groups.

\section{DISCUSSION}

The specific radioactivity of free phenylalanine 40 min after the injection ranged from 19.8 to $20.3 \mathrm{~Bq} /$ nmol, i.e., $\sim 83 \%$ of the specific radioactivity of the injected solution. These values are low compared with those usually found in mammals, but they are very similar to those measured in rainbow trout (Houlihan et al. 1986, McMillan and Houlihan 1988), cod (Houlihan et al. 1988b) and carp (at least at high temperature; Watt et al. 1988). The origin of such a discrepancy between mammals and fish was attributed to the poor vascularization of fish white muscle, which slows amino acid transport into the intracellular compartment (Loughna and Goldspink 1985). This effect is temperature dependent. As suggested by Watt et al. (1988), this effect could induce an error in the absolute values of synthesis, but not in the relative differences between treatments.

The results of the experiment on the time course of incorporation of $\left[{ }^{3} \mathrm{H}\right]$ phenylalanine clearly show that the flooding dose technique is suitable for the study of protein turnover of young sea bass, if the specific radioactivity of the free pool and protein is measured over the $40 \mathrm{~min}$ following the injection of labeled phenylalanine, at least if there is no influence of phenylalanine concentration on protein turnover. This last hypothesis was not tested in our fish;

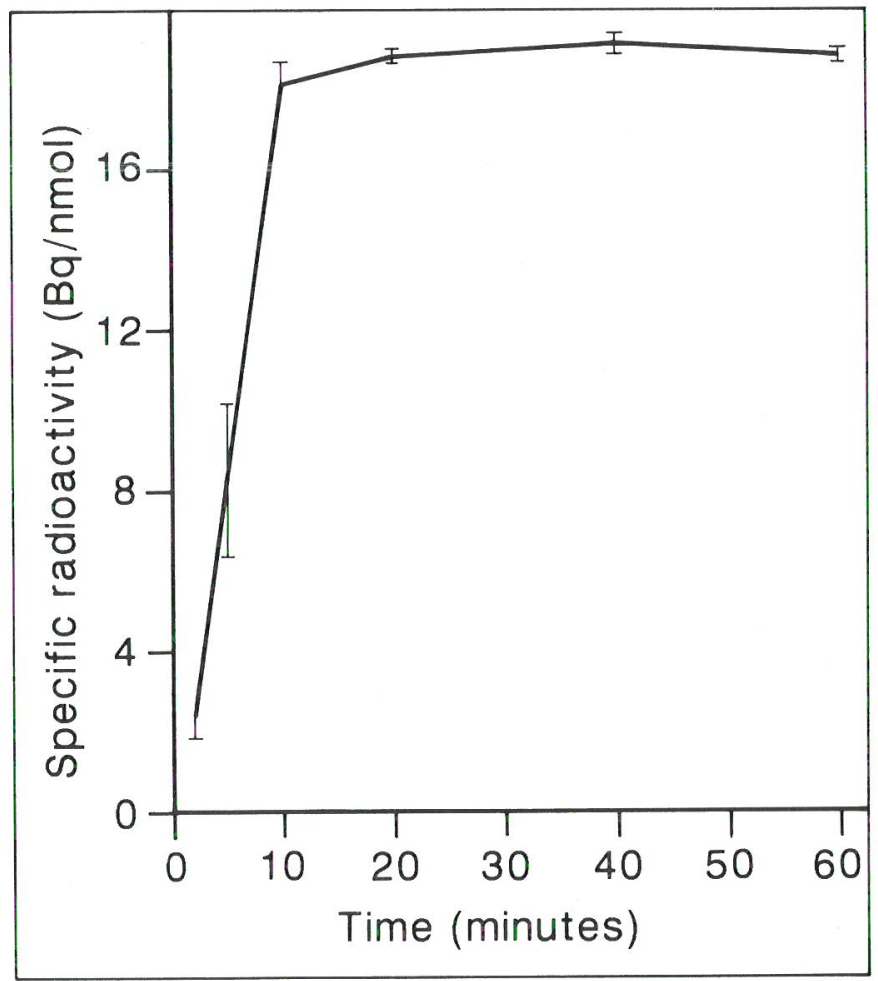

FIGURE 1 Specific radioactivity of the pool of free phenylalanine after the injection of labeled phenylalanine. Results shown are means \pm SEM for 5 individual fish. 
TABLE 5

Fractional protein specific growth rate (Kg), fractional whole-body protein synthesis rate (Ks), fractional whole-body protein degradation rate $(\mathrm{Kd})$ and $\mathrm{RNA} /$ protein ratio of fish fed the experimental diets for $50 d^{1}$

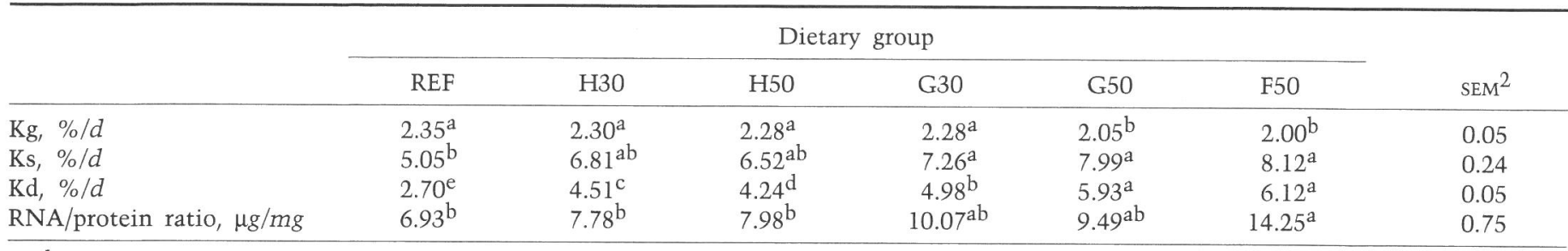

\footnotetext{
${ }^{1}$ Values are means of three pools of 15 fish for $\mathrm{Kg}$ and of 15 individual fish (i.e., five per replicate) for Ks and the RNA/protein ratio. Kd was obtained by difference between $\mathrm{Ks}$ and $\mathrm{Kg}$. Values in a row not sharing a common superscript letter are significantly different $(P<0.05)$.

${ }^{2}$ Pooled SEM from one-way ANOVA.
}

however, it was demonstrated that, in rainbow trout, a large dose of phenylalanine did not affect protein synthesis (Loughna and Goldspink 1985). This conclusion was accepted for sea bass as it is for other vertebrates.

The digestibilities of both nitrogen and energy displayed little variation from diet to diet. Therefore, because fish were fed fixed rations and because digestible protein and energy in diets were comparable and no food was apparently wasted, the vari-

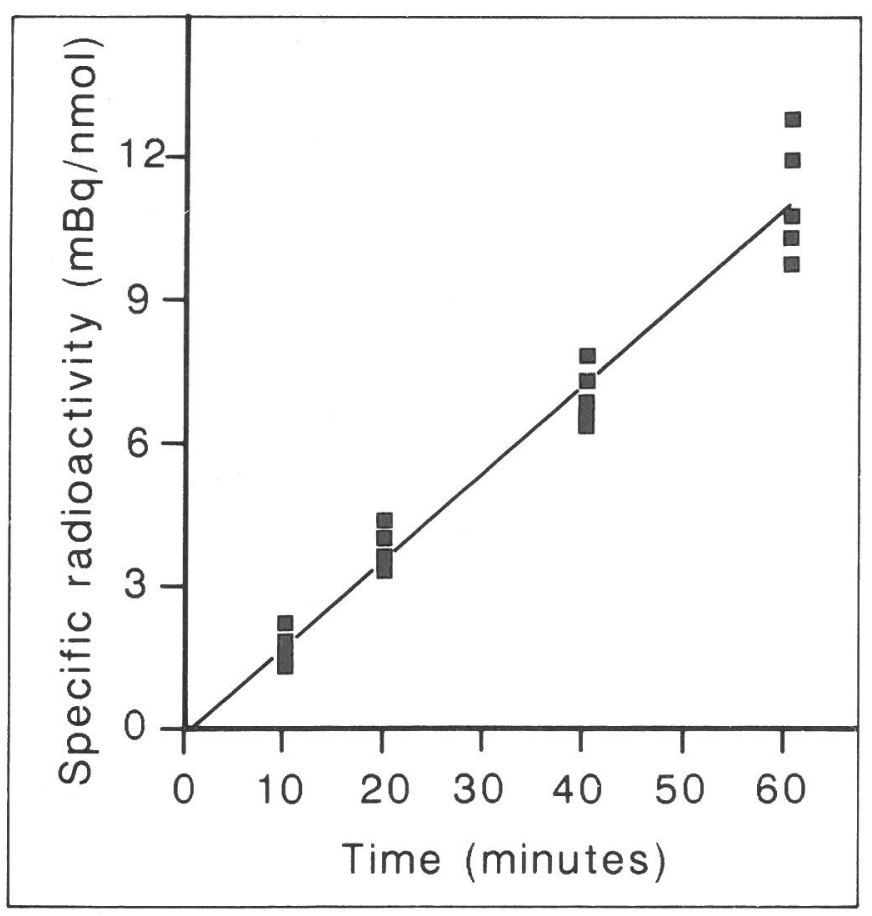

FIGURE 2 Protein-bound specific radioactivity following a flooding dose of labeled phenylalanine at time zero $\ln =5$ individual fish shown by points on the figure; $y=-1.345 \times$ $10^{-4}+1.859 \times 10^{-4} t ; r=0.98$, where $y$ is the protein-bound specific radioactivity of tritiated phenylalanine in $\mathrm{mBq} / \mathrm{min}$ and $t$ is the time in minutes). ation in growth rate is attributable to the essential amino acid balance of digestible protein itself.

Because of the constancy of protein content in the carcass of the different fish groups (the estimated coefficient of variation of individual protein content was $\sim 8 \%$ ) at the start and the end of the experiment, fractional protein specific growth rates $(\mathrm{Kg})$, i.e., fractional protein accretion, vary in the same way as growth rates.

To date, the relationship between growth and protein synthesis has not been explicitly examined in fish fed the same quantity of isoproteinic diets differing only in protein quality. In the present study, whole-body fractional protein synthesis rates tended to be higher with dietary proteins of poor amino acid balance. The lowest efficiency of protein deposition linked to slower growth was also observed in growing cod fed diets distributed at different levels, i.e., when testing protein quantity instead of protein quality (Houlihan et al. 1988b). However, groups fed Diets $\mathrm{H} 30$ and H50, which grew at the same rate as fish fed Diet REF, had an efficiency of protein deposition $27 \%$ lower than for those fed Diet REF (compared with $47 \%$ lower in the group fed Diet F50).

Contrary to results in a previous report (McMillan and Houlihan 1988), the increase of protein synthesis, in this present study, is linked to whole-body RNA content and not to the efficiency of ribosomal activity $\left(\mathrm{K}_{\mathrm{RNA}}\right)$, which did not significantly differ among the experimental groups (Tables 5 and 6). However, our results are in agreement with those observed in tissues of starved fish (Watt et al. 1988). Therefore, protein quality apparently affects protein synthesis in a manner similar to that observed in mammalian skeletal muscle: a reduction in the rate of protein synthesis is linked to a reduction in the amount of RNA (Henshaw et al. 1971, Millward et al. 1973).

Whole-body protein degradation is higher in fish fed protein of poor amino acid balance as well as in fish fed fish hydrolyzate (Table 5). Our results obtained in fish fed proteins of different qualities indicate that the differences in protein accretion are not 
TABLE 6

Efficiency of protein deposition and efficiency of ribosomal activity $\left(K_{R N A}\right)$ in fish fed the experimental diets for $50 d^{1}$

\begin{tabular}{|c|c|c|c|c|c|c|c|}
\hline & \multicolumn{6}{|c|}{ Dietary group } & \multirow[b]{2}{*}{$\operatorname{SEM}^{2}$} \\
\hline & REF & $\mathrm{H} 30$ & $\mathrm{H} 50$ & G30 & G50 & F50 & \\
\hline Efficiency of protein deposition, \% & $46.5^{\mathrm{a}}$ & $33.7^{\mathrm{bc}}$ & $34.9^{\mathrm{b}}$ & $31.4^{\mathrm{c}}$ & $25.7^{\mathrm{d}}$ & $24.7^{\mathrm{d}}$ & 0.7 \\
\hline $\begin{array}{l}\mathrm{K}_{\mathrm{RNA}}{ }^{3} \text { mg synthesized } \\
\text { protein/( } \mu \mathrm{g} \text { RNA.d) }\end{array}$ & 0.72 & 0.90 & 0.85 & 0.75 & 0.85 & 0.60 & 0.07 \\
\hline
\end{tabular}

${ }^{1}$ Values are means of three pools of 15 fish for efficiency of protein deposition and of 15 individual fish for $\mathrm{K}_{\mathrm{RNA}}$. Values in a row not sharing a common superscript letter are significantly different $(P<0.05)$.

${ }^{2}$ Pooled SEM from one-way ANOVA.

${ }^{3} \mathrm{Kg} / \mathrm{Ks}$ expressed as a percentage.

due to a lower protein synthesis rate but to a greater protein breakdown rate, the synthesis being even higher with low quality dietary protein as indicated by the values for Ks and the RNA/protein ratio. This mechanism is similar to that observed in starving Atlantic cod, in which the loss of body protein induced by starvation resulted from an increase of protein degradation associated with a constancy of protein synthesis (Houlihan et al. 1988b). However, in the trial of time course incorporation of radioactivity, fish starved for $3 \mathrm{~d}$ showed a lower protein synthesis, estimated to be $\sim 77 \%$ of that of nonstarved fish. This drop probably results from the initial response of the protein synthesis mechanism to a short-term starvation (Loughna and Goldspink 1984).

To our knowledge, no experiment similar to ours has been performed in fish. In pigs (Fuller et al. 1987) and in chickens (Tesseraud et al. 1992), it was demonstrated that an improvement of protein quality due to lysine supplementation led to results comparable with our data, i.e., that the higher protein accretion is mainly due to the reduction of body protein breakdown and not to a variation in protein synthesis rates. The differences in $\mathrm{Kd}$ observed between fish fed Diet REF and those fed Diet H30 or H50 cannot be due to amino acid balance; they could be due to an effect of a faster amino acid absorption from the digestive tract in fish fed diets containing hydrolyzed fish protein compared with Diet REF. Using the same ingredients, i.e., comparing fish protein hydrolysate to fish protein in diets in which the nature of the protein source was the only difference, S. J. Kaushik (INRA, Saint-Pée sur Nivelle, France, personal communication) observed, in rainbow trout, a faster postprandial increase of aminoacidemia and a higher nitrogen excretion with protein hydrolysate diets. Such a disturbance, not analyzed in our work, could be another factor influencing protein turnover.

Unfortunately, in our study, as well as in previous ones (Goldspink and Kelly 1984, Houlihan et al. 1986 and $1988 \mathrm{~b})$, the calculation of protein degradation is open to criticism, as outlined by Houlihan et al. (1988b). While fractional protein accretion is measured during a 50-d period, synthesis is measured over $40 \mathrm{~min}$. A method of direct measurement of protein degradation would need to be developed for a better study of this phenomenon. Our results emphasize the need for further research on protein degradation in growing fish and on the effect of dietary amino acid balance on the metabolism of essential amino acids as well as body proteins.

\section{LITERATURE CITED}

Bolin, D. W., King, R. P. \& Klosterman, E. W. (1952) A simplified method for the determination of chromic oxide $\left(\mathrm{Cr}_{2} \mathrm{O}_{3}\right)$ when used as an index substance. Science 116: 634-635.

Fuller, M. F., Reeds, P. J., Cadenhead, A. \& Sève, B. (1987) Effects of the amount and quality of dietary protein on nitrogen metabolism and protein turnover of pigs. Br. J. Nutr. 58: 287-300.

Garlick, P. I., McNurlan, M. A. \& Preedy, V. R. (1980) A rapid and convenient technique for measuring the rate of protein synthesis in tissues by injection of ${ }^{3} \mathrm{H}$ phenylalanine. Biochem. J. 217: $507-516$.

Goldspink, D. F. \& Kelly, F. J. (1984) Protein turnover and growth in the whole body, liver and kidney of the rat from foetus to senility. Biochem. J. 76B: 541-543.

Henshaw, E. C., Hirsh, C. A., Morton, B. E. \& Hiatt, H. H. (1971) Control of protein synthesis in mammalian tissues through changes in ribosome activity. J. Biol. Chem. 246: 436-446.

Hirsh, C. A. (1967) Quantitative determination of the ribosomal ribonucleic acid content of liver and novikoff hepatoma from fed and fasted rats. J. Biol. Chem. 242: 2822-2827.

Houlihan, D. F., Agnisola, C., Lyndon, A. R., Gray, C. \& Hamilton, N. M. (1988a) Protein synthesis in a fish heart: responses to increased power output. J. Exp. Biol. 137: 565-587.

Houlihan, D. F., Hall, S. J., Gray, C. \& Noble, B. S. (1988b) Growth rates and protein turnover in Atlantic cod, Gadus morhua. Can. J. Fish Aquat. Sci. 45: 951-964.

Houlihan, D. F., McMillan, D. N. \& Laurent, P. (1986) Growth rates, protein synthesis, and protein degradation rates in rainbow trout: effects of body size. Physiol. Zool. 59: 482-493.

Jones, D. R. \& Randall, D. J. (1978) The respiratory and circulatory systems during exercises. In: Fish Physiology (Hoar, W. S. \& Randall, D. J., eds.), vol. VII, pp. 425-501. Academic Press, New York, NY.

Loughna, P. T. \& Goldspink, G. (1984) The effects of starvation upon protein turnover in red and white myotomal muscle of 
rainbow trout (Salmo gairdneri). J. Fish Biol. 25: 223-230.

Loughna, P. T. \& Goldspink, G. (1985) Muscle protein synthesis rates during temperature acclimation in a eurythermal (Cyprinus carpio) and a steonthermal (Salmo gairdneri) species of teleost. J. Exp. Biol. 118: 267-276.

Lowry, O. H., Rosebrough, N. J., Farr, A. L. \& Randall, R. J. (1951) Protein measurement with the Folin phenol reagent. J. Biol. Chem. 193: 265-275.

McMillan, D. N. \& Houlihan, D. F. (1988) The effect of re- feeding on tissue protein synthesis in rainbow trout. Physiol. Zool. 61: $429-441$.

Mejbaum, W. (1939) Uber die Bestimmung kleiner Pentosmengen, insbesondere in Derivaten der Adenylsaure. Hoppe-Seyler's Z. Physiol. Chem. 258: 117-120.

Millward, D. J., Garlick, P. J., James, W.P.T., Nnanyelugo, D. O. \& Ryatt, J. S. (1973) Relationship between protein synthesis and RNA content in skeletal muscle. Nature (Lond.) 241: 204-205.

Millward, D. J., Garlick, P. J., Stewart, R.J.C., Nnanyelugo, D. O. \& Waterlow, J. C. (1975) Skeletal muscle growth and protein turnover. Biochem. J. 150: 235-243.

Munro, H. N. \& Fleck, A. (1969) Analysis of tissue and body fluids for nitrogeneous constituents. In: Mammalian Protein Metabolism (Munro, H. N., ed.), vol. III, pp. 432-525. Academic Press, New York, NY.

Pain, V. M. \& Clemens, M. J. (1980) Mechanism and regulation of protein synthesis in eukariotic cells. In: Protein Deposition in Animals (Buttery, P. J. \& Lindsay, D. B., eds.), pp. 1-20. Butter- worths, London, U. K.

Pocrnic, Z. R., Mathews, R. W., Rappaport, S. \& Haschemeyer, A.E.V. (1983) Quantitative protein synthetic rates in various tissues of a temperate fish in vivo by the method of the phenylalanine swamping. Comp. Biochem. Physiol. 74B: 735-738.

Tesseraud, S., Larbier, M., Chagneau, A. M. \& Geraert, P. A. (1992) Effect of dietary lysine on muscle protein turnover in growing chickens. Reprod. Nutr. Dev. 32: 163-175.

Ricker, W. E. (1979) Growth rates and models. In: Fish Physiology (Hoar, W. S., Randall, D. J. \& Brett, J. R., eds.), vol. 8, pp. 677-743. Academic Press, New York, NY.

Sokal, R. R. \& Rohlf, F. J. (1981) Biometry. W. H. Freeman, New York, NY.

Spyridakis, P., Gabaudan, J., Métailler, R. \& Guillaume, J. (1988) Digestibilité des protéines et disponibilité des acides aminés de quelques matières premières chez le bar (Dicentrarchus labrax). Reprod. Nutr. Dev. 28: 1509-1517.

Watt, P. W., Marshall, P. A., Heap, S. P., Loughna, P. T. \& Goldspink, G. (1988) Protein synthesis in tissues of fed and starved carp, acclimated to different temperatures. Fish Physiol. Biochem. 4: 165-173.

Young, V. R. (1970) The role of skeletal and cardiac muscle in regulation of protein metabolism. In: Mammalian Protein Metabolism (Munro, H. N., ed.), vol. IV, pp. 586-674. Academic Press, New York, NY. 
